\title{
Epidemiology of intestinal schistosomiasis in ruminants of Bangladesh
}

\author{
M. N. Islam, N. Begum, M. Z. Alam and M. A. A. Mamun \\ Department of Parasitology, Bangladesh Agricultural University, Mymensingh-2202, Bangladesh \\ Email: mamun.dvm@gmail.com
}

\begin{abstract}
We assessed the prevalence and seasonal variations of intestinal schistosomiasis in association with age, sex, breed and rearing system of cattle and goats in different districts of Bangladesh. Fecal samples from 240 cattle and 146 goats were examined. Schistosoma eggs were found in $47.5 \%$ cattle and $43.84 \%$ goats. Two species of schistosomes were identified. No mixed infection was recorded. Prevalence of Schistosoma indicum was higher in cattle $(42.5 \%)$ than in goats $(34.25 \%)$ whereas goats $(9.59 \%)$ were more susceptible to Schistosoma spindale infection than cattle (5.0\%). Age, sex, breed, rearing system and topography of the country had significant $(P<0.01$, $\mathrm{P}<0.05)$ effect on the prevalence of schistosomiasis among cattle, whether only seasons of the year had significant $(P<0.01)$ effect on schistosome prevalence among goats of Bangladesh. Higher infection rate was found in rainy season, in older age group, in males, in local breeds (cattle) and animals reared under semi intensive system. Prevalence was highest in the Rangpur district and lowest in the Dhaka district. The prevalence of intestinal schistosomiasis was very high among cattle and goats in the study area irrespective of age, sex, breed, seasons and rearing system of cattle and goats.
\end{abstract}

Keywords: Epidemiology, Intestinal schistosomiasis, Ruminants, Bangladesh

\section{Introduction}

Schistosomiasis is a snail-brone treamatode infection of domestic animals and man in different parts of Asia and Africa. About 530 million heads of cattle live in areas endemic for cattle schistosomiasis in Africa and Asia while at least 165 million cattle are infected with schistosomes (De Bont and Vercruysse, 1997). Schistosomiasis is now well recognized as the fifth major helminthosis of domestic animals in the Indian sub-continent (Sumanth et al., 2004). This disease is generally chronic in nature and symptoms in majority of animals are insufficient to distinguish the illness from other debilitating infections (De Bont and Vercruysse, 1998). Three types of clinical syndromes are seen in animal infection with schistosomiasis, an acute intestinal, a chronic hepatic and nasal granulomatous syndrome (Lawrence, 1978 and Mulkani, 1933). The species which commonly occur in ruminants in Bangladesh are S. indicum, S. spindale and S. nasale (Rahman et al., 1996).

The epidemiological situation of schistosomiasis must not however, be regarded as static. The increasing use of irrigation in agriculture and fish breeding facilitate to increase number of snails which carry Schistosoma and as a consequence the human and animal incidence of schistosomiasis is increased. Moreover, increasing cattle mobility through trading and or rental increased the possibility of spreading the disease or infection sources. Except for some isolated studies on the prevalence/ incidences of schistosomiasis in Bangladesh (Islam, 1975), country wide data on the prevalence/incidences, transmission, and animals at risk and control aspects have not been addressed.

A pre-requisite for disease control/prevention is to identify factors facilitating identification of categories of animals that are at particular risk at developing an infection (Thrusfield, 1995). So, an in depth understanding of the epidemiology of schistosomiasis is required to develop control strategies. Therefore, the present study was carried out to investigate the prevalence of schistosomiasis in cattle and goat in different districts of Bangladesh. 


\section{Materials and Methods}

\section{Study period and area}

The investigation was carried out over a period of one year from May 2009 to April 2010. Three main seasons can be distinguished in Bangladesh, namely, the cool-dry winter from November to February, the hot-dry summer from March to May and the hot - wet rainy season from June to October (Ahmed et al., 1989). So, the experimental period was divided into these three seasons.

Samples were collected from four districts of Bangladesh, namely, Dhaka, Mymensingh, Rangpur and Kurigram for the convenience of the study and availability of cattle and goats. Coprological examination was conducted in the Department of Parasitology, Bangladesh Agricultural University, Mymensingh.

\section{Selection of cattle and goat}

In total 240 cattle and 146 goats were selected randomly. The age of the animals was between 3 months and 14 years. During collection of samples the age, sex, breed, rearing system of the animals and season of the year were recorded. The age of the animals was determined from the record book where available, or by interrogating the farmers, or by examining the teeth. All animals were categorized into three age groups, such as, calf ( $\leq 1.5$ years), young $(>1.5-\leq 4$ years) and adult ( $>4$ years) in cattle and kid ( $\leq 1$ year), young ( $>1-\leq 2.0$ years) and adult (> 2.0 years) in goat. All examined animals belonged to local and crosses of indigenous with Friesian or Saihiwal in cattle. Only one breed of goats (Black Bengal) was included in this study.

\section{Collection and examination of fecal sample}

The cattle and goats were selected randomly irrespective of age, sex, breed, system of rearing and level of husbandry from the cattle and goat reared in areas as mentioned above. After taking all the relevant information, the faecal samples were collected directly from the rectum. Before collection, the animals were restrained properly and possible hygienic measures including wearing of apron, hand gloves and gumboot were taken to avoid contamination. About 20-25 grams of feces were collected from each animal. Each sample was kept in a separate polythene bag, tied carefully and numbered and the samples were preserved in $10 \%$ formalin. The polythene bags containing the fecal samples with all required information were brought to the laboratory and examined.

The fecal samples were examined by Modified Stoll's Dilution Technique as described by Soulsby (1982). The eggs of schistosomes were identified according to the keys and description by Soulsby (1982) and Rahman et al. (1996).

\section{Statistical analyses}

Chi-square $\left(x^{2}\right)$ test for several prevalences at $1 \%$ or $5 \%$ level of significance (Mostafa,1989) and pair wise significant of several factors (sex, breed and rearing system) one-sided $Z$ test was done (Ahmed et al., 2007).

\section{Results and Discussion}

\section{Overall prevalence of intestinal schistosomiasis in ruminants}

The prevalence of schistosomiasis among cattle and goats was investigated based on the presence of eggs in the fecal samples. Two species of schistosomes were detected, namely, Schistosoma indicum (Fig. 1) and Schistosoma spindale (Fig. 2). It was observed that the prevalence of schistosomiasis was higher in cattle $(47.5 \%)$ than in goats $(43.84 \%)$ (Table 1$)$. A similar trend of infection was also reported in various states of India (Banerjee and Agrawal, 1992 and Rajkhowa et al., 1992). The difference in the prevalence of schistosomiasis in different species of animals is due to variation in the behaviour and feeding system of domesticated animals (Agrawal and Sahastrabudhe, 1982). In contrast to small ruminants, cattle visit regularly and usually contact snail contaminated water when drinking. So a higher propensity for contact with drinking water as a source of contamination could explain the high prevalence of Schistosoma in cattle. Goats show a distinct aversion to immersion in water even avoids walking through it. This may reduce their potential for exposure. 
Table 1. Overall prevalence of intestinal schistosomiasis in ruminants

\begin{tabular}{|l|l|c|c|c|c|}
\hline Type of & \multicolumn{1}{|c|}{$\begin{array}{c}\text { Name of parasites } \\
\text { Animals }\end{array}$} & \multirow{2}{*}{$\begin{array}{c}\text { No. of } \\
\text { identified }\end{array}$} & Prevalence & \multicolumn{2}{|c|}{ Egg per gram of faeces (EPG) } \\
\cline { 5 - 6 } & positive ases & $(\%)$ & Range & Mean \pm SE \\
\hline \multirow{2}{*}{$\begin{array}{l}\text { Cattle } \\
\text { N=240 }\end{array}$} & Schistosoma indicum & 102 & 42.5 & $100-300$ & $124.96 \pm 8.64$ \\
\cline { 2 - 6 } & Schistosoma spindale & 12 & 5.00 & $100-200$ & $46.53 \pm 10.26$ \\
\cline { 2 - 6 } & Subtotal & $\mathbf{1 1 4}$ & $\mathbf{4 7 . 5}$ & $\mathbf{1 0 0 - 3 0 0}$ & $\mathbf{8 5 . 7 5 \pm 9 . 4 5}$ \\
\hline \multirow{2}{*}{$\begin{array}{l}\text { Goat } \\
\mathrm{N}=146\end{array}$} & Schistosoma indicum & 50 & 34.25 & $100-300$ & $144 \pm 9.10$ \\
\cline { 2 - 6 } & Schistosoma spindale & 14 & 9.59 & $100-300$ & $157.14 \pm 20.20$ \\
\cline { 2 - 6 } & Subtotal & $\mathbf{6 4}$ & $\mathbf{4 3 . 8 4}$ & $\mathbf{1 0 0 - 3 0 0}$ & $\mathbf{1 5 0 . 5 7 \pm 1 4 . 6 6}$ \\
\hline
\end{tabular}

$\mathrm{N}=$ Total number of samples examined

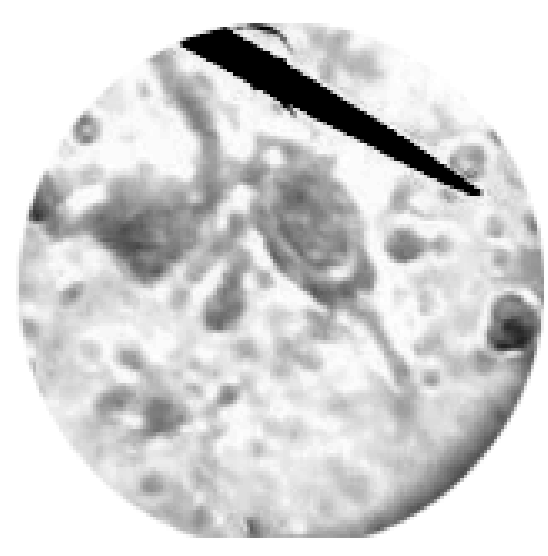

Fig. 1. Ova of Schistosoma indicum

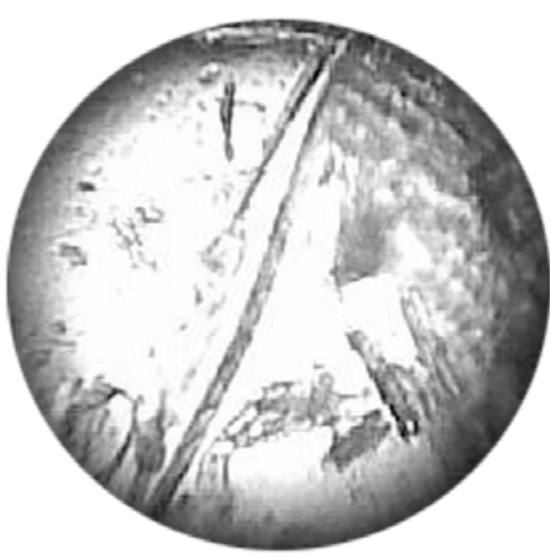

Fig. 2. Ova of Schistosoma spindale

\section{Age related prevalence of intestinal schistosomiasis in ruminants}

Prevalence of schistosomiasis varied ( $p<0.05$ in cattle whereas insignificant in goats) among age groups of cattle and goats. Cattle aged more than 4 years and goat aged more than 2 years showed higher prevalence, but young showed lower prevalence than the calf and kid (Table 2). It also indicated that the infection rate increased with the increase of age and peak infection occurred at the maturity of age which is supported by the findings of Bedarkar et al. (2000). De Bont et al. (1991 also observed that the animals younger than two years were less infected $(21.3 \%)$ than those older than five years $(47.97 \%)$. The high prevalence in adult might be due to a long exposure time as because older animals move long distances in search of scarce pastures and water thereby increasing their chances of infection as well becoming infected at overcrowded watering holes. On the other hand, the very young calf or kid do not graze extensively as the older do, so they get less infection of cercaria like adult animals.

\section{Sex related prevalence of intestinal schistosomiasis in ruminants}

It was detected that prevalence of schistosomiasis was higher ( $p<0.01$ in cattle and insignificant in goats) in male $(65.28 \%$ in cattle and $53.33 \%$ in goats) than in female $(43.29 \%$ in cattle and $41.38 \%$ in goats) ruminants (Table 3). The reason seems to be related to social practice of keeping females under better management and feeding condition for milk production and breeding whether males are generally let lose to graze freely in pasture and infrequently used for draught purpose and also more stressed. Males are also fed relatively poor diet. Poor diet increases the susceptibility to parasitic infection (Houdijk and Athana, 2003). Differences in susceptibility to infection between sexes have been observed by various workers. The observed disparity may not solely due to difference in susceptibility but may also depend on a sex-related variation in behavior that results in differences in exposure (Magona and Musisi, 2002). These findings supported the findings of Asif et al. (2007) who reported a higher prevalence of 
endoparasites in males than females for buffaloes in Pakistan. However, the influence of sex on the susceptibility of animals to infections could be attributed to genetic predisposition and differential susceptibility owing to hormonal control. Further experimental studies are needed to confirm the assumption.

Table 2. Age related prevalence of intestinal schistosomiasis in ruminants

\begin{tabular}{|c|c|c|c|c|c|c|c|}
\hline \multirow[t]{2}{*}{ Animals } & \multirow[t]{2}{*}{ Age } & \multirow{2}{*}{$\begin{array}{l}\text { Name of parasites } \\
\text { identified }\end{array}$} & \multirow{2}{*}{$\begin{array}{l}\text { No. of } \\
\text { positive } \\
\text { cases }\end{array}$} & \multirow{2}{*}{$\begin{array}{c}\text { Prevalence } \\
(\%)\end{array}$} & \multicolumn{2}{|c|}{ Egg per gram of faeces } & \multirow{2}{*}{$\begin{array}{c}\text { Chi-square } \\
\left(x^{2}\right) \text { Value }\end{array}$} \\
\hline & & & & & Range & Mean士 SE & \\
\hline \multirow{9}{*}{ Cattle } & \multirow{3}{*}{$\begin{array}{l}\text { Calf } \\
(\leq 1.5 \text { years }) \\
N=31\end{array}$} & Schistosoma indicum & 9 & 29.03 & $100-200$ & $133.33 \pm 16.67$ & \multirow[t]{9}{*}{$6.47^{*}$} \\
\hline & & Schistosoma spindale & 1 & 3.23 & $100-100$ & $100.00 \pm 0.00$ & \\
\hline & & Subtotal & 10 & 32.26 & $100-200$ & $116.67 \pm 8.33$ & \\
\hline & \multirow{3}{*}{$\begin{array}{l}\text { Young } \\
(>1.5-\leq 4 \text { years }) \\
N=85\end{array}$} & Schistosoma indicum & 32 & 37.64 & $100-300$ & $157.69 \pm 12.62$ & \\
\hline & & Schistosoma spindale & 4 & 4.71 & $100-200$ & $150.00 \pm 28.87$ & \\
\hline & & Subtotal & 36 & 42.35 & $100-300$ & $132.65 \pm 4.01$ & \\
\hline & \multirow{3}{*}{$\begin{array}{l}\text { Adult } \\
(>4-14 \text { years }) \\
N=124\end{array}$} & Schistosoma indicum & 61 & 49.19 & $100-300$ & $165.31 \pm 8.01$ & \\
\hline & & Schistosoma spindale & 7 & 5.65 & $100-100$ & $100.00 \pm 0.00$ & \\
\hline & & Subtotal & 68 & 54.84 & $100-300$ & $153.85 \pm 20.74$ & \\
\hline \multirow{9}{*}{ Goat } & \multirow{3}{*}{$\begin{array}{l}\text { Kid (s1year) } \\
N=18\end{array}$} & Schistosoma indicum & 3 & 16.67 & $100-200$ & $140 \pm 16.33$ & \multirow[t]{9}{*}{$4.24^{\mathrm{NS}}$} \\
\hline & & Schistosoma spindale & 1 & 5.56 & $100-100$ & $100 \pm 0.00$ & \\
\hline & & Subtotal & 04 & 22.23 & $100-200$ & $120.00 \pm 8.16$ & \\
\hline & \multirow{3}{*}{$\begin{array}{l}\text { Young } \\
(>1-\leq 2.0 \text { years }) \\
N=46\end{array}$} & Schistosoma indicum & 14 & 30.43 & $100-300$ & $142.85 \pm 20.20$ & \\
\hline & & Schistosoma spindale & 6 & 13.04 & $100-200$ & $133.33 \pm 21.08$ & \\
\hline & & Subtotal & 20 & 43.48 & $100-200$ & $138.10 \pm 20.64$ & \\
\hline & \multirow{3}{*}{$\begin{array}{l}\text { Adult } \\
(>2-4 \text { years }) \\
N=82\end{array}$} & Schistosoma indicum & 33 & 40.24 & $100-300$ & $146.15 \pm 12.69$ & \\
\hline & & Schistosoma spindale & 7 & 8.54 & $100-300$ & $200 \pm 36.51$ & \\
\hline & & Subtotal & 40 & 48.78 & $100-300$ & $173.08 \pm 24.60$ & \\
\hline
\end{tabular}

$\mathrm{N}=$ Total number of samples examined.

* means $\mathrm{P}<0.05$

NS means insignificant

Table 3. Sex related prevalence of intestinal schistosomiasis in ruminants

\begin{tabular}{|c|c|c|c|c|c|c|c|}
\hline \multirow[t]{2}{*}{ Animals } & \multirow[t]{2}{*}{ Sex } & \multirow{2}{*}{$\begin{array}{l}\text { Name of parasites } \\
\text { identified }\end{array}$} & \multirow{2}{*}{\begin{tabular}{|c|}
$\begin{array}{l}\text { No. of positive } \\
\text { cases }\end{array}$ \\
\end{tabular}} & \multirow{2}{*}{$\begin{array}{c}\text { Prevalence } \\
(\%)\end{array}$} & \multicolumn{2}{|c|}{ Egg per gram of faeces } & \multirow[t]{2}{*}{$\mathrm{Z}$ value } \\
\hline & & & & & Range & Mean \pm SE & \\
\hline \multirow{6}{*}{ Cattle } & \multirow{3}{*}{$\begin{array}{l}\text { Male } \\
N=46\end{array}$} & Schistosoma indicum & 27 & 58.69 & $100-200$ & $145.45 \pm 10.87$ & \multirow[t]{6}{*}{$2.86^{\star *}$} \\
\hline & & Schistosoma spindale & 3 & 6.52 & $0.00-0.00$ & $0.00 \pm 0.00$ & \\
\hline & & Subtotal & 30 & 65.28 & $100-200$ & $145.45 \pm 10.87$ & \\
\hline & \multirow{3}{*}{$\begin{array}{c}\text { Female } \\
\mathrm{N}=194\end{array}$} & Schistosoma indicum & 75 & 38.65 & $100-300$ & $164.52 \pm 7.66$ & \\
\hline & & Schistosoma spindale & 9 & 4.64 & 100.200 & $116.67 \pm 11.24$ & \\
\hline & & Subtotal & 84 & 43.29 & $100-300$ & $88.26 \pm 62.16$ & \\
\hline \multirow{6}{*}{ Goat } & \multirow{3}{*}{$\begin{array}{c}\text { Male } \\
N=30\end{array}$} & Schistosoma indicum & 12 & 40.00 & $100-200$ & $133.33 \pm 21.08$ & \multirow[t]{6}{*}{$1.2^{\mathrm{NS}}$} \\
\hline & & Schistosoma spindale & 4 & 13.33 & $100-100$ & $100 \pm 0.00$ & \\
\hline & & Subtotal & 16 & 53.33 & $100-200$ & $116.67 \pm 10.54$ & \\
\hline & \multirow{3}{*}{$\begin{array}{l}\text { Female } \\
\mathrm{N}=116\end{array}$} & Schistosoma indicum & 38 & 32.76 & $100-300$ & $145.45 \pm 9.99$ & \\
\hline & & Schistosoma spindale & 10 & 8.62 & $100-300$ & $166.67 \pm 22.47$ & \\
\hline & & Subtotal & 48 & 41.38 & $100-300$ & $156.06 \pm 16.24$ & \\
\hline
\end{tabular}

$\mathrm{N}=$ Total number of samples examined

** means $P<0.01$

Ns means insignificant 


\section{Seasonal prevalence of intestinal schistosomiasis in ruminants}

The seasonal prevalence of schistosome infection rate in cattle and goats was higher (insignificant in cattle and $p<0.01$ in goat) in the rainy season than that in the summer (Table 4). The maximum infection of schistosome in rainy season in cattle and goats are comparable with those recorded earlier from different countries with similar or different climatic conditions. The highest infection rate observed in rainy season could be due to abundance of snails (viz. Indoplanorbis, Planorbis, Lymnaea spp.) and their rapid multiplication and dispersion. Furthermore, dispersion of fecal matter occurs due to rain splashes. These factors may enhance the infection of snails by miracidia and cercarial contamination to adjacent areas through water. During this time conditions on the lands are suitable for the survival of the intermediate hosts and they become heavily infected with the schistosome larval stages. So, ruminants are prone to get the infection of schistosomes. There is marked increase in incidence with increasing water conservation and with irrigation and population density of animals (Soulsby, 1982). The results are in agreement with Bedarkar et al. (2000). The higher prevalence rate of schistosomiasis during the monsoon in different districts of Punjab and other adjoining areas in goats (Khajuria and Kapoor; 2003) is also in conformity with our observations. The lower prevalence of fluke infection in summer is also well documented by Bedarkar et al. (2000). The low prevalence in summer could be attributed to harsh dry conditions and less chances of infection due to unavailability of snail intermediate hosts as the water sources are scarce in this season.

Table 4. Seasonal prevalence of intestinal schistosomiasis in ruminants

\begin{tabular}{|c|c|c|c|c|c|c|c|}
\hline \multirow[t]{2}{*}{ Animals } & \multirow[t]{2}{*}{ Age } & \multirow{2}{*}{$\begin{array}{l}\text { Name of parasites } \\
\text { identified }\end{array}$} & \multirow{2}{*}{$\begin{array}{l}\text { No. of } \\
\text { positive } \\
\text { cases }\end{array}$} & \multirow{2}{*}{$\begin{array}{c}\text { Prevalence } \\
(\%)\end{array}$} & \multicolumn{2}{|c|}{ Egg per gram of faeces } & \multirow{2}{*}{$\begin{array}{l}\text { Chi-square } \\
\left(x^{2}\right) \text { Value }\end{array}$} \\
\hline & & & & & Range & Mean士 SE & \\
\hline \multirow{9}{*}{ Cattle } & \multirow{3}{*}{$\begin{array}{c}\text { Summer } \\
N=112\end{array}$} & Schistosoma indicum & 42 & 37.5 & $100-300$ & $138.89 \pm 9.98$ & \multirow[t]{9}{*}{$2.65^{\mathrm{NS}}$} \\
\hline & & Schistosoma spindale & 5 & 4.17 & $100-200$ & $100 \pm 0.00$ & \\
\hline & & Subtotal & 47 & 41.67 & $100-300$ & $72.44 \pm 54.99$ & \\
\hline & \multirow{3}{*}{$\begin{array}{l}\text { Rainy } \\
\mathrm{N}=102\end{array}$} & Schistosoma indicum & 48 & 47.05 & $200-300$ & $175 \pm 6.93$ & \\
\hline & & Schistosoma spindale & 6 & 5.88 & $100-100$ & $100 \pm 0.00$ & \\
\hline & & Subtotal & 54 & 52.93 & $100-300$ & $89.50 \pm 53.47$ & \\
\hline & \multirow{3}{*}{$\begin{array}{l}\text { Winter } \\
N=26\end{array}$} & Schistosoma indicum & 12 & 46.15 & $100-300$ & $175 \pm 31.34$ & \\
\hline & & Schistosoma spindale & 1 & 3.84 & $200-200$ & $200 \pm 0.00$ & \\
\hline & & Subtotal & 13 & 50.00 & $100-300$ & $88.50 \pm 115.67$ & \\
\hline \multirow{9}{*}{ Goat } & \multirow{3}{*}{$\begin{array}{c}\text { Summer } \\
N=76\end{array}$} & Schistosoma indicum & 22 & 28.95 & $100-200$ & $109.09 \pm 6.27$ & \multirow[t]{9}{*}{$12.24^{\star *}$} \\
\hline & & Schistosoma spindale & 2 & 2.63 & $0.00-0.00$ & $0.00 \pm 0.00$ & \\
\hline & & Subtotal & 24 & 31.58 & $100-200$ & $109.09 \pm 6.27$ & \\
\hline & \multirow{3}{*}{$\begin{array}{l}\text { Rainy } \\
N=38\end{array}$} & Schistosoma indicum & 18 & 47.39 & $100-300$ & $160 \pm 15.22$ & \\
\hline & & Schistosoma spindale & 7 & 18.42 & $100-200$ & $125 \pm 16.36$ & \\
\hline & & Subtotal & 25 & 65.79 & $100-300$ & $142.50 \pm 15.79$ & \\
\hline & \multirow{3}{*}{$\begin{array}{l}\text { Winter } \\
\mathrm{N}=32\end{array}$} & Schistosoma indicum & 10 & 31.25 & $100-300$ & $200 \pm 26.73$ & \\
\hline & & Schistosoma spindale & 5 & 15.63 & $100-300$ & $200 \pm 36.51$ & \\
\hline & & Subtotal & 15 & 46.88 & $100-300$ & $200 \pm 31.62$ & \\
\hline
\end{tabular}

$\mathrm{N}=$ Total number of samples examined.

** means $P<0.01$

Ns means insignificant 


\section{Breed related prevalence of intestinal schistosomiasis in cattle}

Local breeds of cattle were more $(P<0.01)$ susceptible than crossbred cattle (Table 5$)$. But, Bedarkar et al. (2000) reported different findings in India. Breed differences in parasitic resistance have been reported for goats in Asia (Baker et al., 2003). But, only one breed black Bengal of goats were included in this study. The difference in the level of parasitism between different breeds of cattle observed in the present study are in agreement with the observation of other workers in various part of the world (Roy et al., 2011), when some breeds were found to be more susceptible to parasitic infections than the others. Some of these variations are due to genetic factors in the host but there are possibilities that the observed differences in resistance may be due to heterosis if the animals are not purebred (Stear and Murray, 1994). It is likely that farmers pay less attention to local cattle than crossbred cattle that may have resulted in the differences.

Table 5. Breed related prevalence of intestinal schistosomiasis in cattle

\begin{tabular}{|c|c|c|c|c|c|c|c|}
\hline \multirow[t]{2}{*}{ Animals } & \multirow[t]{2}{*}{ Breed } & \multirow{2}{*}{$\begin{array}{l}\text { Name of parasites } \\
\text { identified }\end{array}$} & \multirow{2}{*}{$\begin{array}{l}\text { No. of } \\
\text { positive } \\
\text { cases }\end{array}$} & \multirow{2}{*}{$\begin{array}{c}\text { Prevalence } \\
(\%)\end{array}$} & \multicolumn{2}{|c|}{ Egg per gram of faeces } & \multirow[t]{2}{*}{$Z$ value } \\
\hline & & & & & Range & Mean士 SE & \\
\hline \multirow{6}{*}{ Cattle } & \multirow{3}{*}{$\begin{array}{l}\text { Local } \\
N=76\end{array}$} & Schistosoma indicum & 46 & 60.53 & $100-300$ & $173.68 \pm 10.45$ & \multirow[t]{6}{*}{$3.87^{* *}$} \\
\hline & & Schistosoma spindale & 4 & 5.26 & $100-200$ & $150 \pm 28.86$ & \\
\hline & & Subtotal & 50 & 65.79 & $100-300$ & $161.84 \pm 19.66$ & \\
\hline & \multirow{3}{*}{$\begin{array}{l}\text { Crossbred } \\
\qquad N=164\end{array}$} & Schistosoma indicum & 56 & 34.15 & $100-200$ & $147.83 \pm 7.45$ & \\
\hline & & Schistosoma spindale & 8 & 4.88 & $100-100$ & $100 \pm 0.00$ & \\
\hline & & Subtotal & 64 & 39.02 & $100-200$ & $123.91 \pm 3.72$ & \\
\hline
\end{tabular}

$\mathrm{N}=$ Total number of samples examined.

** means $\mathrm{P}<0.01$

\section{Influence of land topography in the prevalence of intestinal schistosomiasis in ruminants}

Infection rate of schistosomiasis varied $(P<0.01$ in cattle whereas insignificant in goat) depending on the places of the country from where samples were collected (Table 6). Prevalence of schistosomiasis differed between states of India (Banerjee and Agrawal, 1992; Rajkhowa et al., 1992). In both cattle and goats, prevalence of schistosomiasis was higher in the Rangpur district and lowest in the Dhaka district. On the other hand, in Mymensingh and Kurigram district, cattle and goats were moderately infected with schistosomiasis. The difference in the prevalence of infection in the different districts of Bangladesh might be due to the difference in the topography and soil and water condition which provide the snail habitat. Highest prevalence in Rangpur might be due to the nature of soils and water and developed irrigation system which provide a favourable snail habitat round year. Moreover, in this area anthelmintic treatment is less frequent as people are not so aware of the deleterious effects of the schistosomes. Organized farming in this area is rear, so farmers pay little attention to their animals. In the contrary, fecal samples from the Dhaka district are mostly collected from the organized farms where routine deworming is common and the animals has less risks to contact with surrounding water bodies. So, infection rate was low. 
Table 6. Influence of land topography in the prevalence of intestinal schistosomiasis in ruminants

\begin{tabular}{|c|c|c|c|c|c|c|c|}
\hline \multirow[t]{2}{*}{ Animals } & \multirow{2}{*}{ Location } & \multirow{2}{*}{$\begin{array}{c}\text { Name of parasites } \\
\text { identified }\end{array}$} & \multirow{2}{*}{\begin{tabular}{|c|}
$\begin{array}{c}\text { No. of positive } \\
\text { cases }\end{array}$ \\
\end{tabular}} & \multirow{2}{*}{$\begin{array}{c}\text { Prevalence } \\
(\%)\end{array}$} & \multicolumn{2}{|c|}{ Egg per gram of faeces } & \multirow{2}{*}{$\begin{array}{l}\text { Chi-square }\left(x^{2}\right) \\
\text { Value }\end{array}$} \\
\hline & & & & & Range & Meant SE & \\
\hline \multirow{12}{*}{ Cattle } & \multirow{3}{*}{$\begin{array}{l}\text { Mymensingh } \\
\mathrm{N}=92\end{array}$} & Schistosoma indicum & 40 & 43.48 & $100-200$ & $152.94 \pm 6.36$ & \multirow[t]{12}{*}{$19.14^{\star \star}$} \\
\hline & & Schistosoma spindale & 2 & 2.17 & $100-100$ & $100 \pm 0.00$ & \\
\hline & & Subtotal & 42 & 45.65 & $100-200$ & $126.47 \pm 4.34$ & \\
\hline & \multirow{3}{*}{$\begin{array}{l}\text { Dhaka } \\
\mathrm{N}=72\end{array}$} & Schistosoma indicum & 18 & 25.0 & $100-200$ & $133.33 \pm 14.21$ & \\
\hline & & Schistosoma spindale & 6 & 8.33 & $100-100$ & $100 . \pm 0.00$ & \\
\hline & & Subtotal & 24 & 33.33 & $100-200$ & $116.67 \pm 7.11$ & \\
\hline & \multirow{3}{*}{$\begin{array}{l}\text { Rangpur } \\
\mathrm{N}=24\end{array}$} & Schistosoma indicum & 18 & 75.0 & $100-300$ & $175 \pm 17.08$ & \\
\hline & & Schistosoma spindale & 2 & 8.33 & $100-100$ & $100 \pm 0.00$ & \\
\hline & & Subtotal & 20 & 83.33 & $100-300$ & $137.50 \pm 8.54$ & \\
\hline & \multirow{3}{*}{$\begin{array}{l}\text { Kurigram } \\
\mathrm{N}=52\end{array}$} & Schistosoma indicum & 26 & 50.0 & $100-300$ & $172.27 \pm 13.45$ & \\
\hline & & Schistosoma spindale & 2 & 3.85 & $200-200$ & $200 \pm 0.00$ & \\
\hline & & Subtotal & 28 & 53.85 & $100-300$ & $186.36 \pm 6.73$ & \\
\hline \multirow{12}{*}{ Goat } & \multirow{3}{*}{$\begin{array}{l}\text { Mymensingh } \\
\mathrm{N}=28\end{array}$} & Schistosoma indicum & 8 & 28.57 & $100-300$ & $200 \pm 26.73$ & \multirow[t]{12}{*}{$2.56^{\mathrm{NS}}$} \\
\hline & & Schistosoma spindale & 6 & 21.43 & $100-300$ & $200 \pm 36.51$ & \\
\hline & & Subtotal & 14 & 50.00 & $100-300$ & $200 \pm 31.62$ & \\
\hline & \multirow{3}{*}{$\begin{array}{l}\text { Dhaka } \\
\mathrm{N}=74\end{array}$} & Schistosoma indicum & 26 & 28.26 & $100-200$ & $115.38 \pm 7.22$ & \\
\hline & & Schistosoma spindale & 2 & 2.17 & $100-100$ & $100 \pm 0.00$ & \\
\hline & & Subtotal & 28 & 37.84 & $100-200$ & $107.69 \pm 3.61$ & \\
\hline & \multirow{3}{*}{$\begin{array}{l}\text { Rangpur } \\
\mathrm{N}=20\end{array}$} & Schistosoma indicum & 8 & 40.00 & $100-200$ & $150 \pm 18.90$ & \\
\hline & & Schistosoma spindale & 3 & 15.00 & $0-0$ & $0.00-0.00$ & \\
\hline & & Subtotal & 11 & 55.00 & $100-200$ & $150 \pm 18.90$ & \\
\hline & \multirow{3}{*}{$\begin{array}{l}\text { Kurigram } \\
\mathrm{N}=24\end{array}$} & Schistosoma indicum & 8 & 33.33 & $100-300$ & $175 \pm 31.34$ & \\
\hline & & Schistosoma spindale & 3 & 12.50 & $100-200$ & $133.33 \pm 21.08$ & \\
\hline & & Subtotal & 11 & 45.83 & $100-300$ & $154.17 \pm 26.21$ & \\
\hline
\end{tabular}

$\mathrm{N}=$ Total number of samples examined.

** means $\mathrm{P}<0.01$

NS means insignificant

\section{Influence of rearing system in the prevalence of intestinal schistosomiasis in ruminants}

Prevalence of schistosomiasis was higher ( $p<0.01$ in cattle and insignificant in goat) in both cattle and goat reared in semi-intensive system than those reared in intensive system (Table 7). Sumanth et al. (2004) reported no cases of schistosomiasis in cattle reared at farms in Bangalore. The lower rate of infection in farm (intensive system) where animals are mainly stall fed, might be due to the better management practices and sanitation. Sumanth et al. (2004) also highlighted the fact that proper management practices alone can minimize the schistosomiasis incidence. But in the semi-intensive system of rearing where animals are grazing in the fields have more risks of getting contact with water and subsequently with the Schistosoma cercaria.

Table 7. Influence of rearing system in the prevalence of intestinal schistosomiasis in ruminants

\begin{tabular}{|c|c|c|c|c|c|c|c|}
\hline \multirow[t]{2}{*}{ Animals } & \multirow{2}{*}{$\begin{array}{l}\text { Rearing } \\
\text { system }\end{array}$} & \multirow{2}{*}{$\begin{array}{l}\text { Name of parasites } \\
\text { identified }\end{array}$} & \multirow{2}{*}{$\begin{array}{l}\text { No. of positive } \\
\text { cases }\end{array}$} & \multirow{2}{*}{$\begin{array}{c}\text { Prevalence } \\
(\%)\end{array}$} & \multicolumn{2}{|c|}{ Egg per gram of faeces } & \multirow[t]{2}{*}{$Z$ value } \\
\hline & & & & & Range & Mean士 SE & \\
\hline \multirow{6}{*}{ Cattle } & \multirow{3}{*}{$\begin{array}{l}\text { Intensive } \\
\mathrm{N}=162\end{array}$} & Schistosoma indicum & 55 & 33.95 & $100-200$ & $150 \pm 10.45$ & \multirow[t]{6}{*}{$4.20^{* *}$} \\
\hline & & Schistosoma spindale & 8 & 4.94 & $100-100$ & $100 \pm 0.00$ & \\
\hline & & Subtotal & 63 & 38.42 & $100-200$ & $125 \pm 3.81$ & \\
\hline & \multirow{3}{*}{$\begin{array}{l}\text { Semi- } \\
\text { intensive } \\
\mathrm{N}=76\end{array}$} & Schistosoma indicum & 47 & 61.84 & $100-300$ & $173.68 \pm 10.45$ & \\
\hline & & Schistosoma spindale & 4 & 5.26 & $100-200$ & $150 \pm 28.87$ & \\
\hline & & Subtotal & 51 & 67.10 & $100-300$ & $161.84 \pm 19.66$ & \\
\hline \multirow{6}{*}{ Goat } & \multirow{3}{*}{$\begin{array}{l}\text { Intensive } \\
\mathrm{N}=64\end{array}$} & Schistosoma indicum & 18 & 29.03 & $100-300$ & $155.56 \pm 16.61$ & \multirow[t]{6}{*}{$1.36^{\mathrm{NS}}$} \\
\hline & & Schistosoma spindale & 6 & 9.68 & $100-300$ & $200 \pm 36.51$ & \\
\hline & & Subtotal & 24 & 37.50 & $100-300$ & $177.78 \pm 26.56$ & \\
\hline & \multirow{3}{*}{\begin{tabular}{|l|} 
Semi- \\
intensive \\
$\mathrm{N}=82$
\end{tabular}} & Schistosoma indicum & 32 & 39.02 & $100-300$ & $137.50 \pm 10.77$ & \\
\hline & & Schistosoma spindale & 8 & 9.76 & $100-200$ & $125 \pm 16.37$ & \\
\hline & & Subtotal & 40 & 48.78 & $100-300$ & $131.25 \pm 13.57$ & \\
\hline
\end{tabular}

$\mathrm{N}=$ Total number of samples examined.

** means $P<0.01$, NS means insignificant 
The present study provides an idea of the status of intestinal schistosomiais in areas studied. Differences of various biotic and ecological factors need to be taken in consideration when designing effective schistisome control management system for these animals. Our present study will be helpful to make strategy for control schistosomiasis in cattle and goat of Bangladesh to prevent economic loss.

\section{References}

Agrawal, M.C. and Sahastrabudhe, V.K. 1982. A note on natural heterologous schistosome infection in domestic animals. Livestock Advisor, 7: 58-59.

Ahmed, A.H., Bhuiya, M.A.A., Reza, Z.A. and Hossain, M.Z. 2007. Methods of Statistics, $2^{\text {nd }}$ edition. pp. 279-280.

Ahmed, T.U., Joshi, G.P., Ahmed, R.U., Dewan, Z.U., Begum, M.N., Akhter, S. and Khoda, M. 1989. Seasonal density of common mosquitoes in jungle area of Modhupur, Tangail. Journal of Zoology, 4:1-14.

Asif, R.M., Iqbal, Z., Jabbar, A. and Yaseen, M. 2007. Point prevalence of gastrointestinal helminthiasis in ruminants in southern Punjab, Pakistan. Journal of Helminthology, 81(3): 323-328.

Baker, R.L., Nagda, S.L., Rodriguez-zas, B.R., Southey, J.O., Audho, E.O., Aduda, S. and Thorpe, W. 2003. Resistance and resilience to gastrointestinal nematode parasites and relationship with productivity of Red Masai, Dorper and Red Massai $\times$ Dorper crossbred lambs in the sub-humid tropics. Animal Science, 76: 119-136.

Banerjee, P.S. and Agrawal, M.C. 1992. Epidemiological studies in bovines on fluke infection with special reference to schistosomosis. Indian Veterinary Journal, 69: 215-220.

Bedarkar, S.N., Narladkar, B.W. and Deshpande, P.D. 2000. Seasonal prevalence of snail fluke infections in ruminants of Marathwada region. Journal of Veterinary Parasitology, 14(1): 51-54.

De Bont, J. and Vercruysse, J. 1997. The epidemiology and control of cattle schistosomiasis. Parasitology Today, 13(7): $255-262$.

De Bont, J. and Vercruysse, J. 1998. Schistosomiasis in cattle. Advances in Parasitology, 41: 286-363.

De Bont, J., Vercruysse, J. Van Aken, D., Southgate, V.R., Rollinson, D. and Moncrieff, C. 1991. The epidemiology of Schistosoma spindale Montgomery, 1906 in cattle in Srilanka. Parasitology, 102: 237-241.

Houdijk, J.G.M. and Athana, S.S.A. 2003. Direct and indirect effects of host nutrition on ruminants gastrointestinal parasites. In: Proceedings of the sixth International symposium on the nutrition of herbivores. Merida Mexico.

Islam, K.S. 1975. Schistosomiasis in domestic ruminants in Bangladesh. Tropical Animal Health and Production, 7(4): 244-248.

Khajuria, J.K. and Kapoor, P.R. 2003. Prevalence of parasites in sheep and goats in Kathua-Jannu. Journal of Veterinary Parasitology, 17: 121-126.

Lawrence, J.A. 1978. The pathology of S. mattheei infection in ox 2. Lesions attributable to the adult parasites. Journal of Comparative Pathology, 88: 15-29.

Magona, J.W. and Musisi, G. 2002. Influence of age, grazing system, season and agro climatic zone on the prevalence and intensity of gastrointestinal strongylosis in Ugandan goats. Small Ruminants Research, 44: 187-192.

Mostafa, M.G. 1989. Methods of statistics, Fourth edition, Karim Press and Publications, Dhaka, pp. 289-298.

Mulkani, P.G. 1933. Discover of the cause of nasal granuloma in cattle, preliminary report. Indian Veterinary Journal, 9: $257-277$.

Rahman, M.H., Ahmed, S. and Mondol, M.M.H. 1996. Introduction to Helminth Parasites of Animals and Birds in Bangladesh. 1st ed., Sheba Printing Press, Dhaka, Bangladesh. pp. 58-59.

Rajkhowa, C., Gogoi, A.R., Borkakoty, M.R. and Das, M. 1992. Incidance of Schistosomes in cattle, buffalo and goats in Assam. Indian Veterinary Journal, 69: 273-275.

Roy, B.C., Mondal, M.M.H., Majumder, S. and Talukder, M.H. 2011. Epidemiological study on the Balantidium coli in cattle at Mymensingh of Bangladesh. Bangladesh. Journal of Progressive Science and Technology, 9(2): 145-148.

Soulsby, E.J.L. 1982. Helminths, Arthropods and Protozoa of Domesticated Animals. $7^{\text {th }}$ Ed. English Language Book Society and Baillere Tindall, London. pp. 763-772.

Stear, M.J. and Murray, M. 1994. Genetic resistance to parasitic disease; particulary of resistance in ruminants to gastro-intestinal nematodes. Veterinary Parasitology, 17: 121-126.

Sumanth, S.S., Souza, P.E. and Jagannath, M.S. 2004. A study of nasal and Intestinal schistosomiasis in cattle slaughtered at an abattoir in Bangalore South India. Revista Science Technology, 23: 937- 942.

Thrusfield, M. 1995. Veterinary Epidemiology, Second edition. Blakwell Science Ltd, London, UK. 